Monika Czajkowska

https://doi.org/10.26881/pwe.2021.52.08

ORCID: 0000-0003-2162-304X

Akademia Pedagogiki Specjalnej im. Marii Grzegorzewskiej

mczajkowska@aps.edu.pl

\title{
Klaudia Mróz
}

Przedszkole nr 296 „Bajkowy Parasol” w Warszawie

\section{Nauczyciele wychowania przedszkolnego i klas I-III wobec edukacji matematycznej z wykorzystaniem nowych technologii ${ }^{1}$}

\section{Summary \\ Pre-school education teachers and primary school teachers towards mathematical education with the use of new technologies}

In this article, we present partial results of research aimed at identifying how pre-school education and primary school (grades I-III) teachers use new technologies resources in mathematics education. 110 teachers participated in the study. The basic research method was an internet questionnaire. Our research has shown that many pre-school education and primary school (grades I-III) teachers, especially those with 10 years of work experience and more, show a high pedagogical awareness. When conducting mathematics education classes, they use both conventional teaching aids and new technologies resources, and try to maintain the right proportions. However, in the times of the COVID-19 pandemic, conducting remote math education for a significant proportion of the teachers surveyed turned out to be a big challenge. The typical difficulties to teaching mathematics were combined with difficulties related to distance education and difficulties resulting from the attitude (reluctance) of parents, and sometimes children, to mathematics or learning this subject.

Keywords: pre-school education teachers, primary school teachers, new technologies, mathematics

Słowa kluczowe: nauczyciele wychowania przedszkolnego, nauczyciele klas I-III, nowe technologie, matematyka

\section{Nowe technologie w życiu współczesnych dzieci}

Współczesne dzieci od najmłodszych lat (często od okresu niemowlęctwa) mają styczność z technologiami informacyjno-komunikacyjnymi (TIK). Doświadczają wzrokowo-słuchowo-dotykowo-myślowego kontaktu z różnymi urządzeniami medialnymi (Jędrzejko,

1 Artykuł zawiera fragmenty niepublikowanej pracy magisterskiej Klaudii Mróz (2020). 
Morańska 2013: 236), zwłaszcza telewizorami (Özdaşli, Göl 2013: 1018-1019), smartfonami i komputerami (Walter 2012: 427; Bąk 2015: 4; Chojak 2015: 85). Dotychczas nie zbadano dokładnie, jaki wpływ mają TIK na rozwój małego dziecka. Z różnych badań wynika, że nadmierne korzystanie z nich może prowadzić do: problemów z rozwojem mowy i komunikacją, wzrostu występowania schematyzmów i zaburzeń w relacjach społecznych (Chojak 2015: 92-93), trudności z koncentracją, wad wzroku, wad postawy i do otyłości (Sosnowska-Bielicz, Wrótniak 2013: 152). Jacek Pyżalski (2017: 164-170) charakteryzuje zagrożenia związane $\mathrm{z}$ wykorzystywaniem TIK przez dzieci w wieku przedszkolnym - zwraca uwagę na następujące zagrożenia: 1) rozwoju fizycznego dziecka; 2) rozwoju poznawczego dziecka; 3) rozwoju emocjonalnego i społecznego dziecka; 4) związane $z$ dominującą pozycją TIK w aktywności dziecka na tle innych jego aktywności; 5) związane z wykorzystywaniem TIK online.

Z kolei nie można nie dostrzegać, że TIK stały się jednym z elementów kontekstu społeczno-wychowawczego najmłodszego pokolenia (Holtkamp 2011; Bąk 2015). W obecnych czasach wychowanie dziecka $\mathrm{z}$ dala od urządzeń elektronicznych jest po prostu niemożliwe. Dzieci codziennie obserwują, jak dorośli używają narzędzi cyfrowych i multimediów. Zauważają, że są one nieodłącznym elementem ich życia. Jak pisze Jürgen Holtkamp: „dzieci są wszystkiego ciekawe, przeżywają, gdy ich rodzice (...) pracują przy komputerze, a ponieważ to oni są ich pierwszymi wzorami do naśladowania, gorliwie starają się im dorównać" (2011: 15-16). Nie dziwi więc, że w naturalny sposób dzieci dążą to kontaktu ze smartfonami, z tabletami czy komputerami. Co więcej, te urządzenia są dla nich bardzo atrakcyjne. Dają im poczucie sprawstwa. Wystarczy, że dziecko kliknie lub przesunie odpowiednio rączką. Już roczne dzieci z zainteresowaniem i skupieniem obserwują na ekranie urządzenia mobilnego efekty swoich działań, a niektóre czterolatki rozumieją zasady prostych gier komputerowych i wiedzą, jakie ruchy ręką należy wykonać lub co przyciskać, aby poruszać postaciami gier.

Nowe technologie pojawiły się zarówno w domach dzieci, jak i w przedszkolach i szkołach. Należy podkreślić, że poglądy naukowców na temat ich używania w edukacji, zwłaszcza w przedszkolach, są podzielone. Jedni twierdzą, że mogą one wyrządzić dzieciom wiele szkody. Edyta Gruszczyk-Kolczyńska pisze, że wykorzystywanie TIK w przedszkolach „zapowiada trudną do przewidzenia pułapkę wychowawczą" (2017: 332). Jej zdaniem może to zaburzyć harmonijny rozwój dziecka, gdyż nie będzie ono potrafiło odróżnić rzeczywistości od świata wirtualnego. Jan Jelinek (2012: 110) zauważa, że dostępne na rynku programy multimedialne nie przechodzą kontroli jakości, a wydawcy nie prowadzą badan, których celem byłoby ustalenie ich efektywności edukacyjnej. Z przeprowadzonych przez niego badań wynika, że program Klik uczy liczyć nie wpływa na nabywanie przez uczniów wiadomości i umiejętności matematycznych (Jelinek 2012: 124-125).

Inni badacze są zdania, że TIK mogą, a nawet powinny być używane już w edukacji przedszkolnej i wczesnoszkolnej. Michał Klichowski i in. (2017: 118-120) uważają, że TIK wykorzystywane w przemyślany sposób przez odpowiedzialnego dorosłego, zachowującego umiar w ich stosowaniu, mogą ,pozytywnie stymulować rozwój poznawczy 
dzieci”. Dorota Klus-Stańska (2013: 6) stwierdza, że „cyfrowy świat” nie tylko nie zaszkodzi dziecku, ale da mu szansę na wszechstronny rozwój. Umożliwi samodzielne odkrywanie wiedzy, wzbogaci proces dydaktyczny i tym samym zagwarantuje jego większą skuteczność. Ewa Szymanowska (2009: 42) zwraca uwagę, że komputer, przy spełnieniu pewnych warunków, może być wykorzystywany już w pracy z dziećmi 3-5-letnimi. Natalia Walter (2012: 431-432) opisuje zajęcia, w których programy komputerowe były skutecznie wykorzystywane do rozwijania określonych umiejętności matematycznych dzieci przedszkolnych. W swoich badaniach Renata Kozieł (2007: 162-164) wykazała, że uczniowie klas I szkoły podstawowej, którzy w trakcie nauki korzystali z programów multimedialnych, osiągnęli umiejętności arytmetyczne na takim samym lub wyższym poziomie niż ci, którzy nabywali te same umiejętności w tradycyjny sposób, bez użycia komputera.

Jednocześnie Klus-Stańska (2013) zauważa, że nauczyciele i szkoły obawiają się zmian, jakie zachodzą przy wprowadzaniu nowych technologii. Choć pojawienie się w szkołach komputerów wpłynęło na: stosowane przez nauczycieli metody nauczania, sposoby przygotowywania przez nich pomocy dydaktycznych, pozyskiwanie informacji i komunikowanie się z uczniami, ich rodzicami czy innymi nauczycielami (Makiewicz 2010: 120), nauczyciele jednak bardzo rzadko wykorzystują nowe technologie na zajęciach z edukacji matematycznej. Co więcej, robią to głównie w celu ich uatrakcyjnienia (Rybak 2011: 125; Białek i in. 2013: 175). Dystans nauczycieli do TIK wynika z różnych powodów. Ruben Hermans i in. (2008: 1506-1507) twierdzą, że istotne są tu: płeć nauczyciela, jego doświadczenie w kontaktach z nowymi technologiami i ogólne nastawienie do komputera. Do innych ważnych czynników należy zaliczyć: brak przekonania o efektywności nauczania z wykorzystaniem TIK, przeświadczenie o negatywnym wpływie TIK na rozwój dziecka, brak odpowiednich elektronicznych materiałów dydaktycznych lub ich nieznajomość, brak odpowiednich kompetencji cyfrowych, brak odpowiedniego wyposażenia placówek w multimedia (Rybak 2011; Czajkowska i in. 2015; Czajkowska 2020). I choć nadal w opinii wielu nauczycieli wyposażenie placówek edukacyjnych w urządzenia multimedialne nie jest wystarczające (Czajkowska 2020; Mróz 2020), obecnie coraz więcej nauczycieli deklaruje stosowanie narzędzi cyfrowych w edukacji matematycznej, w tym zadań w wersji elektronicznej (Czajkowska 2020). Powiększa się też grono nauczycieli, którzy samodzielnie projektują komputerowe materiały dydaktyczne i wykorzystują je w swojej pracy (Szymanowska 2009: 42; Czajkowska 2020: 229). Mimo to niektórzy z nich tylko pozorują nowoczesne nauczanie. W rzeczywistości prowadzą tradycyjne lekcje, na których dominuje praca frontalna i metody oparte na przekazie wiedzy (Czajkowska 2020). Podobne wnioski wynikają z badań prowadzonych przez Lucynę Kopciewicz (2020). Wykazała ona, że nauczycielki wczesnej edukacji, choć oczekują zmian, nie zawsze mają „odwagę je projektować i realizować” i mimo że tablet staje się użytecznym narzędziem, nie jest on ,narzędziem zmiany”.

Wybuch pandemii COVID-19 w pewnym stopniu przyczynił się do znaczącego wzrostu wykorzystania nowych technologii w edukacji, w tym edukacji matematycznej. Nauczyciele zostali postawieni przed koniecznością nauczania zdalnego. Wielu z nich musiało 
podwyższyć swoje kompetencje cyfrowe, nauczyć się obsługi narzędzi cyfrowych, poznać programy wspomagające nauczanie matematyki, wypracować nowe metody $\mathrm{i}$ techniki pracy.

Dlatego postanowiłyśmy sprawdzić, jakie programy, strony internetowe i portale edukacyjne wspomagające nauczanie matematyki po dwóch miesiącach nauczania zdalnego znają nauczyciele wychowania przedszkolnego i klas I-III i które z nich wykorzystują w swojej pracy. Chciałyśmy rozpoznać opinie nauczycieli na temat wpływu stosowania nowych technologii na efektywność nauczania matematyki i dowiedzieć się, które umiejętności matematyczne rozwijają z ich użyciem.

\section{Metodologia badań}

W dalszej części artykułu opisujemy fragment szerszych badań dotyczących stosowania nowych technologii na zajęciach z edukacji matematycznej w przedszkolu i klasach I-III. Badania te zostały przeprowadzone przez Klaudię Mróz (2020) w ramach pracy magisterskiej. Ich celem było rozpoznanie, w jaki sposób nauczyciele deklaratywnie wykorzystują nowe technologie do rozwijania umiejętności matematycznych dzieci w wieku przedszkolnym oraz wczesnoszkolnym, zwłaszcza w okresie pandemii COVID-19. Dążono do ustalenia, czy są $\mathrm{w}$ tym zakresie jakieś różnice między nauczycielami pracującymi w przedszkolach i w szkołach oraz nauczycielami o różnym stażu pracy. Biorąc pod uwagę własne obserwacje oraz dane, takie jak: długość ścieżki awansu zawodowego, średni wiek nauczycieli w Polsce, wiek nauczycieli z pokolenia milenialsów, badanych nauczycieli podzielono na dwie grupy: ze stażem mniejszym niż 10 lat i tych z dłuższym stażem - 10 lat i więcej.

Sformułowano m.in. następujące pytania badawcze:

- Jakie programy komputerowe, strony internetowe lub portale edukacyjne znają nauczyciele wychowania przedszkolnego i nauczyciele klas I-III i które z nich wykorzystują, przygotowując się do zajęć, a które na zajęciach z edukacji matematycznej?

- Czy są jakieś różnice w znajomości i stosowaniu programów komputerowych, stron internetowych lub portali edukacyjnych na zajęciach $z$ edukacji matematycznej przez nauczycieli wychowania przedszkolnego i nauczycieli klas I-III lub nauczycieli o stażu pracy mniejszym niż 10 lat i nauczycieli o stażu pracy 10 lat i większym?

- Czy w opinii nauczycieli wychowania przedszkolnego i nauczycieli klas I-III wykorzystywanie komputera w bezpośredniej pracy z dziećmi podnosi jakość edukacji matematycznej?

- W jaki sposób nauczyciele prowadzą edukację matematyczną zdalnie w czasie pandemii COVID-19 i jakie napotykają trudności? 
W badaniach zastosowano metodę sondażu diagnostycznego i technikę ankiety internetowej. Jesteśmy świadome niedostatków tej metody, jednak w czasie pandemii - gdy zamknięto placówki edukacyjne i ograniczono kontakty międzyludzkie - użycie innych metod było niemożliwe.

W kwestionariuszu zamieszczono, oprócz metryczki, 22 pytania, które dotyczyły: znajomości i wykorzystywania przez nauczycieli programów komputerowych, stron internetowych i portali edukacyjnych, opinii nauczycieli na temat ich użyteczności w nauce matematyki, wyposażenia placówek w multimedia, opinii nauczycieli dotyczących przydatności TIK do wspierania konkretnych umiejętności matematycznych. Ostatni blok pytań dotyczył zdalnego nauczania matematyki oraz współpracy nauczycieli z rodzicami w okresie pandemii COVID-19. Ankieta została utworzona w formularzu Google i udostępniona na grupach społecznościowych nauczycieli przedszkolnych i nauczycieli klas I-III na portalu Facebook. Udział w badaniach był anonimowy i dobrowolny.

Badania przeprowadzono w okresie maj-sierpień 2020 r. Wypełnione ankiety przesłało 110 osób, wśród których było 109 kobiet i jeden mężczyzna. Większość stanowili nauczyciele pracujący w przedszkolu (73 osoby). Szczegółowe informacje na temat wieku i stażu pracy nauczycieli zamieszczono w tabeli 1 .

Tabela 1. Wiek i staż pracy nauczycieli $(\mathrm{N}=110)$

\begin{tabular}{|l|c|c|c|c|c|}
\hline \multirow{2}{*}{ Zmienna } & \multicolumn{5}{|c|}{ Wskaźniki } \\
\cline { 2 - 6 } & M & ME & SD & MIN & MAX \\
\hline Wiek & 33,11 & 30 & 8,78 & 22,0 & 58 \\
\hline Staż pracy & 8,13 & 5 & 8,53 & 0,5 & 39 \\
\hline
\end{tabular}

M - średnia; Me - mediana; SD - odchylenie standardowe; MIN - wartość minimalna; MAX wartość maksymalna

Źródło: badania własne.

Do analiz zebranego materiału badawczego wykorzystano programy: Excel i Statistica. W analizach posłużono się testem niezależności chi-kwadrat oraz testem U Manna-Whitneya na poziomie istotności 0,1 .

\section{Wyniki badań}

\section{Programy komputerowe i narzędzia TIK} wykorzystywane do przygotowania zajęć z edukacji matematycznej

Spośród programów komputerowych, wykorzystywanych przez nauczycieli do przygotowania zajęć z edukacji matematycznej, najczęściej wskazywano: Word (79,1\%, 87 osób) oraz Power Point (70,9\%, 78 osób). Wśród innych wymienianych programów były np. Photoshop, Workspace. Szczegółowe informacje zamieszczono w tabeli 2. 
Tabela 2. Programy komputerowe wykorzystywane przez badanych nauczycieli do przygotowania zajęć $(\mathrm{N}=110)$

\begin{tabular}{|l|c|c|c|c|c|}
\hline \multirow{2}{*}{ Wskaźniki } & \multicolumn{5}{|c|}{ Program } \\
\cline { 2 - 6 } & Word & Power Point & Paint & Excel & inne \\
\hline Liczba osób & 87 & 78 & 43 & 20 & 7 \\
\hline Odsetek (\%) & 79,1 & 70,9 & 39,1 & 18,2 & 6,4 \\
\hline
\end{tabular}

Źródło: badania własne.

Program Word jest najczęściej używanym programem, zarówno w grupie nauczycieli przedszkolnych, jak i wczesnoszkolnych. W analizach statystycznych wykazano, że nie ma istotnych różnic między wykorzystywaniem programów: Word, Excel i Paint przez nauczycieli obu grup. Statystyczną istotność między obiema grupami nauczycieli otrzymano jedynie w przypadku wykorzystywania programu Power Point $\left(\mathrm{chi}^{2}=3,543, \mathrm{p}=0,06\right)$. Program ten jest w większym stopniu wykorzystywany przez nauczycieli przedszkolnych.

W testach chi-kwadrat nie stwierdzono statystycznie istotnej zależności między stażem pracy a programami wykorzystywanymi do przygotowywania zajęć.

Nauczyciele, przygotowując zajęcia z edukacji matematycznej, korzystają z bardzo wielu narzędzi TIK. Łącznie zostało wymienionych ponad 50 różnych stron internetowych oraz portali edukacyjnych (np. Kahoot!, LearningApps, Quizziz, Genially, Eduelo, Digipuzzle, Squla, MiniMini, SuperKid, Szalone liczby, Matematyka Plus), kilka stron wydawnictw edukacyjnych (np. www.mac.pl, www.blizejprzedszkola.pl) oraz kilka grup na portalach społecznościowych, zrzeszających nauczycieli przedszkolnych lub wczesnoszkolnych (np. pani Monia). Najczęściej nauczyciele wskazywali kilka stron lub portali. Tylko 9 badanych zadeklarowało, że przygotowując zajęcia, w ogóle nie korzysta z TIK.

\section{Znajomość stron internetowych oraz portali edukacyjnych przeznaczonych do wspomagania edukacji matematycznej w przedszkolu lub w klasach I-III}

Znajomość stron internetowych oraz portali edukacyjnych przeznaczonych do wspomagania edukacji matematycznej w przedszkolu lub w klasach I-III zadeklarowało $86,4 \%$ badanych (95 osób). Wskazano takie strony internetowe lub portale, jak: Scholaris, Matzoo, Kahoot!, Buliba.pl, Ciufcia.pl oraz Lulek.tv.

W teście chi-kwadrat nie wykazano statystycznie istotnych zależności między miejscem pracy nauczycieli (przedszkole vs szkoła) a ogólną znajomością stron internetowych lub portali edukacyjnych użytecznych w nauczaniu i uczeniu się matematyki (chi ${ }^{2}$ $=1,895, \mathrm{p}=0,173)$.

Na podstawie dokładniejszych analiz stwierdzono, że obie grupy nieco się różnią, biorąc pod uwagę konkretne strony internetowe lub portale edukacyjne. Statystycznie istotną zależność otrzymano między miejscem pracy nauczycieli a znajomością Matzoo oraz Ciufcia.pl (tab. 3). Nauczyciele pracujący w szkołach znają oba te portale edukacyjne w większym stopniu niż nauczyciele pracujący w przedszkolach. 
Tabela 3. Nauczyciele wychowania przedszkolnego i klas I-III a znajomość konkretnych stron internetowych lub portali edukacyjnych użytecznych w nauczaniu matematyki $(\mathrm{N}=95)$

\begin{tabular}{|l|c|c|c|c|c|c|}
\hline Wskaźniki & Matzoo & Lulek.tv & Scholaris & Buliba.pl & Kahoot! & Ciufcia.pl \\
\hline chi $^{2}$ & 7,548 & 0,726 & 0,011 & 0,031 & 0,000 & 4,235 \\
\hline $\mathrm{p}$ & 0,006 & 0,394 & 0,915 & 0,860 & 0,989 & 0,040 \\
\hline
\end{tabular}

Źródło: badania własne.

W teście chi-kwadrat wykazano statystycznie istotną zależność między stażem pracy nauczycieli (poniżej 10 lat vs 10 lat i więcej) a ogólną znajomością stron internetowych lub portali edukacyjnych użytecznych w nauce matematyki $\left(\mathrm{chi}^{2}=5,029, \mathrm{p}=0,025\right)$. Co ciekawe, większą znajomością takich stron internetowych lub portali wykazywali się nauczyciele o dłuższym stażu pracy. Statystycznie istotną zależność otrzymano pomiędzy stażem pracy a znajomością stron: Buliba.pl i Kahoot! (tab. 4).

Tabela 4. Staż pracy a znajomość konkretnych stron internetowych lub portali edukacyjnych $(\mathrm{N}=95)$

\begin{tabular}{|l|c|c|c|c|c|c|}
\hline \multirow{2}{*}{ Wskaźniki } & \multicolumn{7}{|c|}{ Portal edukacyjny/ strona internetowa } \\
\cline { 2 - 7 } & Matzoo & Lulek.tv & Scholaris & Buliba.pl & Kahoot! & Ciufcia.pl \\
\hline chi $^{2}$ & 0,051 & 0,676 & 2,479 & 3,979 & 3,286 & 1,955 \\
\hline $\mathrm{p}$ & 0,822 & 0,411 & 0,115 & 0,046 & 0,070 & 0,162 \\
\hline
\end{tabular}

Źródło: badania własne.

Nauczyciele ze stażem pracy 10 lat i więcej częściej deklarowali znajomość Buliba.pl, zaś nauczyciele z mniejszym stażem pracy - Kahoot!

\section{Korzystanie ze stron internetowych, portali edukacyjnych i aplikacji, przeznaczonych do wspomagania edukacji matematycznej w przedszkolu lub w klasach I-III}

Wykorzystanie w bezpośredniej pracy z dziećmi stron internetowych lub portali edukacyjnych użytecznych w nauce matematyki zdeklarowały już tylko 82 osoby (74,5\%). Nauczyciele, którzy odpowiedzieli, że z nich nie korzystają, wyjaśniali, że: nie czują takiej potrzeby, nie są przekonani o skuteczności nauczania z użyciem TIK albo nie dysponują odpowiednim sprzętem, oprogramowaniem lub dobrym łączem. Niektórzy nie podawali przyczyn, ale pisali, że np. korzystają ,jedynie z pomocy namacalnych, tzn. liczmanów".

Nauczyciele, którzy wykorzystują w pracy z dziećmi strony internetowe i portale edukacyjne, zazwyczaj wskazywali te same strony i portale, które wymieniali w pytaniu wcześniejszym. Wyniki zestawiono w tabeli 5. 
Tabela 5. Strony internetowe lub portale edukacyjne, z których korzystają badani nauczyciele $(\mathrm{N}=82)$

\begin{tabular}{|l|c|c|c|c|c|c|c|}
\hline \multirow{2}{*}{ Wskaźniki } & \multicolumn{7}{|c|}{ Portal edukacyjny/ strona internetowa } \\
\cline { 2 - 8 } & Matzoo & Scholaris & Lulek.tv & Buliba.pl & Kahoot! & Ciufcia.pl & inne \\
\hline Liczba osób & 42 & 40 & 30 & 20 & 20 & 15 & 16 \\
\hline Odsetek (\%) & 51 & 49 & 37 & 24 & 24 & 18 & 20 \\
\hline
\end{tabular}

Źródło: badania własne.

W testach chi-kwadrat nie wykazano statystycznie istotnej zależności między miejscem pracy nauczycieli (przedszkole $v s$ szkoła) a ogólnym korzystaniem ze stron internetowych lub portali edukacyjnych użytecznych w nauczaniu i uczeniu się matematyki $\left(\mathrm{chi}^{2}=0,119, \mathrm{p}=0,730\right)$. Stwierdzono natomiast statystycznie istotną zależność pomiędzy miejscem pracy a korzystaniem z konkretnych stron internetowych: Lulek.tv i Matzoo (tab. 6). Pierwszą z nich w większym stopniu wykorzystują nauczyciele pracujący w przedszkolach, a drugą - nauczyciele klas I-III.

Tabela 6. Nauczyciele wychowania przedszkolnego i klas I-III a korzystanie z konkretnych stron internetowych lub portali edukacyjnych $(\mathrm{N}=82)$

\begin{tabular}{|l|c|c|c|c|c|c|}
\hline \multirow{2}{*}{ Wskaźniki } & \multicolumn{7}{|c|}{ Portal edukacyjny/ strona internetowa } \\
\cline { 2 - 7 } & Matzoo & Lulek.tv & Scholaris & Buliba.pl & Kahoot! & Ciufcia.pl \\
\hline chi $^{2}$ & 2,905 & 4,210 & 1,534 & 0,202 & 0,009 & 0,280 \\
\hline $\mathrm{p}$ & 0,088 & 0,040 & 0,215 & 0,653 & 0,926 & 0,597 \\
\hline
\end{tabular}

Źródło: badania własne.

W testach chi-kwadrat wykazano istotną zależność między stażem pracy (poniżej 10 lat vs 10 i więcej lat) a ogólnym korzystaniem ze stron internetowych lub portali edukacyjnych użytecznych w nauczaniu i uczeniu się matematyki $\left(\mathrm{chi}^{2}=4,926, \mathrm{p}=0,026\right)$. Deklaratywnie w większym stopniu sięgają po nie nauczyciele ze stażem pracy 10 lat lub więcej. Na podstawie testów chi-kwadrat stwierdzono statystycznie istotne zależności między stażem pracy a korzystaniem z portali: Buliba.pl oraz Ciufcia.pl (tab. 7). Oba portale są częściej wykorzystywane przez nauczycieli o dłuższym stażu pracy.

Tabela 7. Staż pracy a korzystanie z konkretnych stron internetowych lub portali edukacyjnych $(\mathrm{N}=82)$

\begin{tabular}{|l|c|c|c|c|c|c|}
\hline \multirow{2}{*}{ Wskaźniki } & \multicolumn{6}{|c|}{ Portal edukacyjny/strona internetowa } \\
\cline { 2 - 7 } & Matzoo & Lulek.tv & Scholaris & Buliba.pl & Kahoot! & Ciufcia.pl \\
\hline chi $^{2}$ & 0,156 & 0,440 & 0,984 & 4,461 & 0,333 & 4,874 \\
\hline $\mathrm{p}$ & 0,693 & 0,505 & 0,321 & 0,035 & 0,564 & 0,027 \\
\hline
\end{tabular}

Źródło: badania własne. 
Na pytanie o to, czy nauczyciele używają aplikacji do prowadzenia zajęć z dziećmi, 75 osób udzieliło odpowiedzi twierdzącej. Wszystkie te osoby korzystają z darmowych aplikacji, a dodatkowo 21 spośród nich zdecydowało się na aplikacje płatne. Wśród aplikacji wymienianych przez nauczycieli były m.in.: Kahoot!, Genially.

\section{Opinie nauczycieli na temat wpływu TIK na podniesienie jakości edukacji matematycznej}

Nie wykazano statystycznie istotnych różnic w poglądach nauczycieli wychowania przedszkolnego i nauczycieli klas I-III na temat wpływu TIK na podniesienie jakości edukacji matematycznej. Większość badanych w obu grupach uważa, że wpływ ten jest znaczący lub umiarkowany. Natomiast istnieją statystycznie istotne zależności między miejscem pracy nauczyciela (przedszkole $v s$ szkoła) a opiniami na temat wpływu TIK na rozwijanie niektórych konkretnych umiejętności matematycznych dzieci. W teście U Manna-Whitneya wykazano statystycznie istotne różnice między nauczycielami przedszkolnymi i wczesnoszkolnymi w poglądach na temat wpływu TIK na rozwój logicznego myślenia oraz umiejętności liczenia i wykonywania działań matematycznych (tab. 8).

Tabela 8. Opinie nauczycieli wychowania przedszkolnego i klas I-III na temat wpływu TIK na rozwijanie niektórych konkretnych umiejętności matematycznych dzieci

\begin{tabular}{|l|l|c|c|c|}
\hline Umiejętność & Nauczyciele & M rang & Z & p \\
\hline \multirow{2}{*}{ Logiczne myślenie dziecka } & przedszkole & 51,57 & \multirow{2}{*}{$-2,012$} & 0,044 \\
\cline { 2 - 3 } & szkoła & 63,26 & \\
\hline \multirow{2}{*}{$\begin{array}{l}\text { Liczenie i wykonywanie } \\
\text { działań matematycznych }\end{array}$} & przedszkole & 51,47 & \multirow{2}{*}{$-1,946$} & 0,049 \\
\cline { 2 - 3 } & szkoła & 63,45 & \\
\hline
\end{tabular}

Źródło: badania własne.

W obu przypadkach wyższe średnie rang uzyskali nauczyciele pracujący w szkołach. W przypadku opinii na temat wpływu TIK na rozwój: koncentracji uwagi i spostrzegawczości dzieci, orientacji w przestrzeni, dostrzegania i kontynuowania rytmów, dostrzegania prawidłowości, rozpoznawania figur geometrycznych i klasyfikowania nie stwierdzono statystycznie istotnych różnic pomiędzy obiema grupami nauczycieli.

\section{Zdalna edukacja matematyczna w czasach pandemii COVID-19}

W okresie pandemii COVID-19 badani nauczyciele najczęściej kontaktowali się z dziećmi i ich rodzicami za pomocą poczty elektronicznej (38,2\%), Facebooka lub Messengera $(34,5 \%)$. Relatywnie często na Facebooku zostały utworzone grupy, do których należeli nauczyciel i rodzice dzieci, których on uczył. Wśród innych kanałów komunikacji wymieniane były: Zoom, Teams i Skype oraz kontakt telefoniczny. Znacznie rzadziej 
wskazywano Google Meet oraz WhatsApp. Sześć osób pracujących w przedszkolach podało, że w ogóle nie kontaktowało się z dziećmi ani z ich rodzicami. Cztery z nich, odpowiadając na pozostałe pytania ankiety, zadeklarowały, że w ogóle nie wykorzystują TIK w edukacji najmłodszych.

Nauczyciele stosowali dwie drogi nauczania zdalnego: przesyłali materiały do pracy dziecka w domu lub prowadzili zajęcia online. Te dwie drogi się nie wykluczają - część badanych wskazywała, że wykorzystują oba sposoby. Nauczyciele, którzy zadeklarowali, że prowadzą z dziećmi zajęcia online, robili to głównie z użyciem aplikacji Zoom $(19,1 \%)$ oraz Teams $(10,9 \%)$.

Wymieniane przez nauczycieli trudności z prowadzeniem zdalnej edukacji matematycznej w większości pokrywały się z dostrzeganymi ogólnymi trudnościami prowadzenia nauki zdalnej. Do najczęściej podawanych należały: trudności techniczne (problemy związane z Internetem, sprzętem i jego obsługą, brak możliwości połączenia się z wszystkimi dziećmi, brak odpowiedniego przeszkolenia w zakresie prowadzenia nauki zdalnej, trudności z montowaniem filmów), trudności metodyczne (brak możliwości sprawdzania poprawności zadań wykonanych przez dzieci, brak możliwości udzielenia pomocy „tu i teraz" dzieciom mającym trudności z wykonaniem konkretnego zadania), trudności komunikacyjne (brak kontaktu z rodzicami lub chęci współpracy ze strony rodziców, brak informacji zwrotnych zarówno ze strony dzieci, jak i rodziców), problemy emocjonalno-motywacyjne (małe zaangażowanie dzieci w naukę, rozdrażnienie dzieci, frustracja rodziców i nauczycieli). Do typowych trudności związanych z edukacją matematyczną należy zaliczyć: brak możliwości wyjaśniania konkretnych treści matematycznych (np. jak liczyć na konkretach lub na liczmanach, jak posługiwać się linijką), brak dostępu do pomocy dydaktycznych użytecznych w nauczaniu matematyki i znajdujących się w placówce, brak odpowiednich zadań w wersji elektronicznej, brak odpowiedniej wiedzy matematycznej i metodycznej rodziców, preferencje rodziców dotyczące ograniczenia nauki zdalnej do przesyłania kart pracy (zarówno w przedszkolu, jak i w szkole), niechęć dzieci lub rodziców do matematyki. Niektórzy nauczyciele wskazywali, że wymienione trudności powodują sprowadzenie edukacji matematycznej do „,papierowej matematyki”.

Co czwarty nauczyciel $(25,5 \%)$ podał, że nie napotyka żadnych trudności z prowadzeniem edukacji matematycznej w sposób zdalny.

\section{Dyskusja}

Zdecydowana większość badanych, przygotowując się do zajęć z edukacji matematycznej, deklaratywnie korzysta z programów komputerowych. Zarówno w grupie nauczycieli wychowania przedszkolnego i klas I-III najczęściej wykorzystywany jest Word, który służy głównie do tworzenia materiałów dydaktycznych (np. wycinanek, kolorowanek, kart pracy), nie jest natomiast stosowany w bezpośredniej pracy z dziećmi. Wielu nauczycieli poszukuje w zasobach Internetu ciekawych rozwiązań metodycznych, pomysłów na za- 
jęcia matematyczne oraz gotowych materiałów. Korzystają oni z różnych stron internetowych i portali edukacyjnych. Wymieniają się pomysłami na grupach społecznościowych. Niektórzy samodzielnie przygotowują interaktywne zadania matematyczne w formie gier, zabaw czy quizów. W tym celu wykorzystują m.in.: Kahoot!, LearningApps, Quizziz, Genially, Eduelo.

Około trzech na czterech nauczycieli stosuje, przynajmniej czasami, rozwiązania zamieszczone na stronach internetowych lub portalach edukacyjnych w bezpośredniej pracy z dziećmi do wspierania ich edukacji matematycznej. Nauczyciele pracujący w szkołach wskazywali głównie Matzoo, a nauczyciele wychowania przedszkolnego - Lulek.tv. Nie jest to zaskakujące, gdyż serwis internetowy Matzoo jest adresowany do dzieci uczęszczających do szkoły, Lulek.tv zaś - do dzieci przedszkolnych.

Ciekawym wynikiem jest to, że nauczyciele ze stażem pracy 10 lat i więcej wykazują się większą znajomością portali edukacyjnych lub stron internetowych użytecznych w nauczaniu matematyki i w większym stopniu deklarują ich stosowanie w praktyce przedszkolnej lub szkolnej. Możliwe, że wynika to z ich większej świadomości pedagogicznej. Zauważają, jak przeobraża się świat, jak na przestrzeni lat zmieniają się dzieci uczęszczające do przedszkoli i szkół, i ciągle poszukują nowych rozwiązań dydaktycznych, które będą atrakcyjne dla najmłodszego pokolenia, od urodzenia obeznanego ze zdobyczami nowych technologii. Warto zwrócić uwagę, że zdecydowana większość nauczycieli dąży do łączenia tradycyjnego (bez TIK) i nowoczesnego (z TIK) nauczania matematyki. Z jednej strony są świadomi, że kształtowanie umiejętności matematycznych dzieci odbywa się w wyniku gromadzenia przez nie osobistych doświadczeń, nabywanych w trakcie eksperymentowania i manipulowania na konkretach lub zbiorach zastępczych. Z drugiej zaś zauważają, że przedszkole lub szkoła nie mogą być „oderwane” od rzeczywistości. Nauczanie matematyki formalne i nieformalne, szkolne lub pozaszkolne to tylko różne drogi nabywania kompetencji matematycznych przez dzieci. Te drogi nie powinny być rozłączne, a tym bardziej nie powinny się od siebie oddalać. Powinny się wielokrotnie krzyżować, przenikać i wzajemnie uzupełniać. Powinny prowadzić do jednego celu przygotowania dzieci do funkcjonowania we współczesnym świecie i do sprostania wyzwaniom, jakie niesie ten świat, szczególnie do wykorzystywania wiedzy i umiejętności matematycznych w praktyce.

Dla znaczącej części badanych prowadzenie zdalnej edukacji matematycznej okazało się dużym wyzwaniem. Na typowe trudności związane z edukacją zdalną nałożyły się trudności typowe dla zdalnego nauczania matematyki oraz trudności wynikłe z podejścia (niechęci) rodziców, a czasami również dzieci do matematyki lub nauki tego przedmiotu. Na podstawie wypowiedzi nauczycieli można wnioskować, że zdalne nauczanie matematyki wielokrotnie sprowadzało się do ,papierowej matematyki”. Nauczyciel przygotowywał karty pracy, które wysyłał do rodziców. Rodzice je drukowali, dzieci rozwiązywały zadania, a następnie rodzice wysyłali nauczycielowi do sprawdzenia wypełnione karty pracy. Jednak takie nauczanie matematyki jest dydaktycznie błędne. Nie sprzyja ono nabywaniu odpowiednich kompetencji matematycznych. Jest to nauczanie algorytmiczne, 
ukierunkowane na naukę gotowych schematów postępowania i zapamiętanie kolejnych kroków rozwiązywania typowych zadań, a nie na rozwój myślenia matematycznego. Istnieje zatem realne zagrożenie, że pomimo dobrych chęci i starań zarówno ze strony nauczycieli, jak i rodziców dzieci nauczane matematyki w ten sposób na kolejnych etapach edukacyjnych będą miały jeszcze większe trudności z nauką tego przedmiotu niż obecnie.

W badaniu pokazano też, że pomimo stosowania TIK w edukacji matematycznej nadal dominuje transmisyjny przekaz informacji przez nauczycieli, który tym różni się od kształcenia tradycyjnego, że dokonywany jest za pomocą nowych narzędzi.

\section{Konkluzja}

Wielu nauczycieli wychowania przedszkolnego i klas I-III wykazuje się dużą świadomością pedagogiczną. Wykorzystują w edukacji matematycznej zarówno konwencjonalne pomoce dydaktyczne, jak i narzędzia cyfrowe, starają się przy tym zachować odpowiednie proporcje. Robią to jednak niejako po omacku i na wyczucie. Kierują się intuicją oraz poczynionymi obserwacjami. Ciągle „poszukują”, łącząc się w grupy wsparcia i wymieniając doświadczeniami.

Wielu nauczycieli czuje się osamotnionych w swoich staraniach. Nie otrzymali odpowiedniego przeszkolenia w zakresie wykorzystania TIK w edukacji. Czasami placówki, w których pracują, nie są wystarczająco wyposażone w multimedia lub mają kiepską jakość łącz internetowych. Nauczyciele nie mają też odpowiedniego wsparcia w przypadku problemów ze sprzętem lub oprogramowaniem. Warto zauważyć, że zdecydowana większość nauczycieli nie ma wykształcenia informatycznego, a wymagane jest od nich, aby radzili sobie w razie awarii sprzętu lub oprogramowania. Dlatego nauczyciele często odczuwają związany z tym dyskomfort, a nawet lęk. Nauczanie zdalne z jednej strony zwiększyło ich kompetencje cyfrowe, z drugiej zaś spotęgowało te negatywne emocje i wywołało frustrację. Wydaje się, że w obecnych czasach właściwym rozwiązaniem byłoby zatrudnienie w każdej placówce informatyka dostępnego w trakcie pracy nauczycieli, serwisującego sprzęt komputerowy i udzielającego nauczycielom wsparcia technicznego. Wprawdzie w szkołach nauczyciele informatyki pełnią często również funkcję administratora sieci, jednak w dobie powszechnej cyfryzacji i pojawiających się problemów, jest to niewystarczające. Ponadto nauczyciel informatyki często nie może udzielić na bieżąco wsparcia innym nauczycielom, ponieważ sam w tym czasie prowadzi lekcje.

Innym ważnym problemem jest niewielki zasób elektronicznych materiałów do nauczania matematyki o sprawdzonej wartości dydaktycznej. Choć materiałów w Internecie jest dużo i ciągle pojawiają się nowe, do tej pory nie przeprowadzono zbyt wielu badań, których celem byłoby określenie ich wartości dydaktycznej i przydatności do rozwijania konkretnych umiejętności matematycznych. Niestety, czasami już pobieżny ogląd takich materiałów ujawnia ich niedostatki dydaktyczne, a nawet błędy merytoryczne. 
Jeszcze innym palącym problemem jest przeszkolenie nauczycieli w zakresie wykorzystywania portali i stron internetowych do wspomagania procesu uczenia się matematyki. Nawet najlepiej przygotowane elektroniczne materiały dydaktyczne, gdy są niewłaściwie wykorzystywane, mogą przynieść więcej szkody niż pożytku.

\section{Literatura}

Bąk A. (2015), Korzystanie z urządzeń mobilnych przez małe dzieci w Polsce. Warszawa, Fundacja Dzieci Niczyje. https://fdds.pl/co-robimy/raporty-z-badan/2015/korzystanie-z-urzadzen-mobilnych-przez-male-dzieci-w-polsce-2015.html, 10.08.2019.

Białek K., Biedrzycki K., Brożek A., Czajkowska M., Dobkowska J., Dobosz J., Grudniewska M., Stanaszek A., Wróbel I., Zambrowska M. (2013), Raport z badania. Szkoła samodzielnego myślenia. Warszawa, IBE. https://www.ibe.edu.pl/images/diagnoza_matematyki/ibe-raport-szkola-samodzielnego-myslenia.pdf, 30.06.2020.

Chojak M. (2015), Nowe technologie a rozwój wybranych procesów poznawczych u dzieci w wieku przedszkolnym i wczesnoszkolnym. W: K. Denek, A. Kamińska, P. Oleśniewicz (red.), Edukacja jutra. Nowe Technologie w ksztatceniu. Sosnowiec, Wyższa Szkoła Humanitas.

Czajkowska M. (2020), Modern mathematics teaching with the use of computer based tasks - reality or myth? „Edukacyjna Analiza Transakcyjna”, 9.

Czajkowska M., Grochowalska M., Orzechowska M. (2015), Potrzeby nauczycieli edukacji wczesnoszkolnej i nauczycieli matematyki w zakresie rozwoju zawodowego. Warszawa, IBE. http:// produkty.ibe.edu.pl/index.php?id=94, 30.06.2020.

Gruszczyk-Kolczyńska E. (2017), Tabletowe dzieci. Ile zła wyrzadza małym dzieciom tablet reklamowany jako najlepsza zabawka dla twojego dziecka. Ku rozwadze dorostym, którzy temu ulegają. „Szkoła Specjalna”, 78(5).

Hermans R., Tondeur J., van Braak J., Valcke M. (2008), The impact of primary school teachers' educational beliefs on the classroom use of computers. „Computers \& Education”, 51.

Holtkamp J. (2011), Co ogtupia nasze dzieci? Nowe media jako wyzwanie dla rodziców. Kraków, Wydawnictwo Salwator.

Jelinek J. (2012), Edukacja medialna małego dziecka - (bez)błędnie realizowana konieczność. W: M. Kotarba-Kańczugowska (red.), Wyzwania współczesnej edukacji przedszkolnej. Warszawa, Wydawnictwo Akademii Pedagogiki Specjalnej.

Jędrzejko M., Morańska D. (2013), Pułapki współczesności. Cz. 1: Cyfrowi Tubylcy. Socjopedagogiczne aspekty nowych technologii cyfrowych. Dąbrowa-Górnicza-Warszawa, Wyższa Szkoła Biznesu w Dąbrowie Górniczej, Oficyna Wydawnicza ASPRA-JR.

Klichowski M., Pyżalski J., Kuszak K., Klichowska A. (2017), Jak technologie informacyjno-komunikacyjne moga wspierać rozwój dziecka w wieku przedszkolnym? - studium teoretyczne. W: J. Pyżalski (red.), Małe dzieci w świecie technologii informacyjno-komunikacyjnych - pomiędzy utopijnymi szansami a przesadzonymi zagrożeniami. Łódź, Wydawnictwo „Eter”.

Klus-Stańska D. (2013), Cyfrowi tubylcy w szkole cyfrowych imigrantów, czyli awantura w świecie Ptysia i Balbinki. Warszawa, Polskie Towarzystwo Pedagogiczne.

Kopciewicz L. (2020), Czy pojawienie się technologii informacyjno-komunikacyjnych w klasie szkolnej oznacza zmiane praktyk nauczania i uczenia się? „Problemy Wczesnej Edukacji”, 50(3). 
Kozieł R. (2007), Komputer w procesie ksztattowania umiejętności arytmetycznych uczniów klas wczesnoszkolnych. „Chowanna”, 2.

Makiewicz M. (2010), Nauka matematyki z komputerem. W: Kozielska M. (red.), Technologie informacyjne w poznawaniu wiedzy matematyczno-przyrodniczej. Toruń, Wydawnictwo Adam Marszałek.

Mróz K. (2020), Wykorzystanie technologii informacyjnych $w$ rozwijaniu umiejętności matematycznych dzieci $w$ wieku przedszkolnym $i$ wczesnoszkolnym. Niepublikowana praca magisterska napisana pod kierunkiem M. Czajkowskiej. Warszawa, Akademia Pedagogiki Specjalnej w Warszawie.

Özdaşli E., Göl M. (2013), Media and Television in Child Education. „Procedia - Social and Behavioral Sciences", 106. https://www.researchgate.net/publication/270745992_Media_and_Televisison_in_Child_Education, 15.04.2021.

Pyżalski J. (2017), Dzieci w wieku przedszkolnym w świecie technologii informacyjno-komunikacyjnych - w stronę zagrożeń. W: J. Pyżalski (red.), Małe dzieci w świecie technologii informacyjno-komunikacyjnych - pomiędzy utopijnymi szansami a przesadzonymi zagrożeniami. Łódź, Wydawnictwo „Eter”.

Rybak A. (2011), Tradycyjne i nowoczesne środki w edukacji. W: T. Lewowicki, B. Siemieniecki, Technologie edukacyjne - tradycja, wspótczesność, przewidywana przyszłość. Toruń, Wydawnictwo Adam Marszałek.

Sosnowska-Bielicz E., Wrótniak J. (2013), Nawyki żywieniowe a otyłość dzieci. „Lubelski Rocznik Pedagogiczny", 32.

Szymanowska E. (2009), Komputer w nauczaniu przedszkolnym $i$ wczesnoszkolnym z perspektywy kompetencji ucznia i nauczyciela. W: E. Baron-Polańczyk (red.), Komputerowe wspomaganie dydaktyki. Zielona Góra, Uniwersytet Zielonogórski.

Walter N. (2012), Komputer w edukacji przedszkolnej. W: W. Skrzydlewski, S. Dylak (red.), Media-Edukacja-Kultura. Poznań-Rzeszów, Polskie Towarzystwo Technologii i Mediów Edukacyjnych. 